\title{
Pola Asuh Orang Tua Yang Otoriter Dalam Keluarga (Dampak Perkembangan Perilaku Anak Di Desa Kaloling kecamatan Sinjai Timur Kabupaten Sinjai)
}

\author{
Oleh : Ismail ${ }^{1}$ \\ Institut Agama Islam Muhammadiyah Sinjai
}

\begin{abstract}
Abstrak
Orang tua merupakan pendidik utama bagi anak-anak mereka, karena dari merekalah anak mulai menerima pendidikan.Dengan demikian bentuk pertama dari pendidikan terdapat dalam kehidupan keluarga ${ }^{2}$ Keluarga adalah tempat pengasuhan alami yang melindungi anak yang baru tumbuh dan merawatnya, serta mengembangkan fisik, akal, dan spiritualitasnya.Dalam naungan keluarga, perasaan cinta, empati, dan solidaritas berpadu dan menyatu. Anakanak pun akan bertabiat dengan tabiat yang biasa dilekati sepanjang hidupnya. ${ }^{3}$ Orang tua memiliki tanggung jawab untuk mendidik, mengasuhdan membimbing anak-anaknya untuk mencapai tahapan tertentu yangmenghantarkan anak untuk siap dalam kehidupan bermasyarakat.
\end{abstract}

\section{Kata kunci : Pola Asuh, Prilaku, Perkembangan Anak}

\footnotetext{
${ }^{1}$ Dosen Institut Agama Islam Muhammadiyah Sinjai

${ }^{2}$ Zakiah Daradjat, et.al., Ilmu Pendidikan Islam, (Cet. IX; Jakarta: Bumi Aksara, 2011), h. 35

${ }^{3}$ Mahmud Al Jauhari dan Muhammad Abddul Hakim Khayyal, Membangun keluarga Qurani,
} (Cet. I: Amzah, 2005), h. 6 


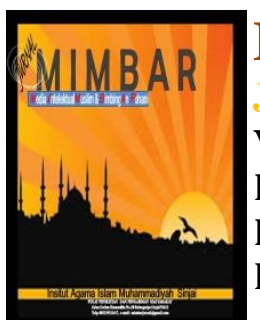

MIMBAR

Jurnall Media Intelektual Muslim dan Bimbingan Rohani

Volume 5, No. 2, 2019

ISSN (print) : 2442-3217

ISSN (online) : 2716-3806

Homepage : http://journal.iaimsinjai.ac.id/indeks.php/mimbar

\section{PENDAHULUAN}

\section{A. Latar Belakang Masalah}

Keluarga merupakan suatu grup sosial primer yang didasarkanpada ikatan perkawinan (hubungan suami-istri) dan ikatan kekerabatan (hubunganantar generasi, orang tua dengan anak). Namun secara dinamis individu yangmembentuk sebuah keluarga dapat digambarkan sebagai anggota dari kelompokmasyarakat yang paling dasar yang tinggal bersama dan berinteraksi untukmemenuhi kebutuhan individu maupun antar individu mereka.

Setiap keluarga menginginkan yang namanya keharmonisan dan kebahagiaan, jauh dari masalah dan saling mencintai, tetapi pada kenyataanya banyak keluarga yang tidak merasa nyaman, anak yang merasa tertekan oleh keadaan keluarganya dan bahkan sedih karena kurangnya kedamaian dalam keluarganya.Kekerasan bisa bersifat fisik, psikologis, maupun dalam bentuk penelantaran.Kondisis yang demikian cenderung menganggu pertumbuhan dan perkembangan mental anak, sehingga mereka tidak bisa tumbuh dan berkembang secara natural.

Di Desa Kaloling Kecamatan Sinjai Timur, masih sering di jumpai orang tua yang selalu menghukum anak yang tidak mematuhi aturan dan tidak mengikuti atau melaksanakan semua perintah orang tua yang telah di tetapkan. Ada orang tua yang memukul anaknya ketika melanggar perintahnya, memarahi anak yang melakukan kesalahan sehingga anak takut melakukan sesuatu tanpa perintah dari orang tua. 


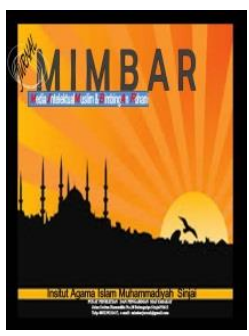

MIMBAR

Jurnall Media Intelektuall Muslim dan Bimbingan Rohani

Volume 5, No. 2, 2019

ISSN (print) : 2442-3217

ISSN (online) : 2716-3806

Homepage : http://journal.iaimsinjai.ac.id/indeks.php/mimbar

Anak yang dididik dengan pola asuh yang otoriter akan merasa

takut,bingung,merasa bersalah,cenderung suka melawan dan melakukan kekerasan

karena meniru perilaku orang tua. Orang tua yang mengasuh anak yang otoriter di sebabkan karena kurangnya pendidikan orang tua sehingga tidak memahami pola asuh yang sesungguhnya.Untuk dapat menyelamatkan pertumbuhan dan perkembangan anak secara optimal, kiranya perlu dilakukan penanganan secara psikologis dan pendekatan kepada kedua orang tua.

Karena keluarga merupakan kelompok sosial yang pertama dimana anak dapatberinteraksi, maka pengaruh keluarga dalam pembentukan dan perkembangankepribadian sangatlah penting. Banyak faktor dalam keluarga yang ikutberpengaruh dalam proses perkembangan anak.Salah satu faktor dalam keluarga yang mempunyai peranan penting dalampembentukan kepribadian adalah praktik pengasuhan anak.

Orang tua mempunyai berbagai macam fungsi terutama mengasuh putraputrinya dengan baik. Dalam mengasuh anaknya orang tua dipengaruhioleh budaya yang ada di lingkungannya. Di samping itu, orang tua juga diwarnaioleh sikap-sikap tertentu dalam memelihara, membimbing, dan mengarahkanputra-putrinya. Sikap tersebut tercermin dalam pola pengasuhan kepada anaknya yang berbeda-beda, karena orang tua mempunyai pola pengasuhan tertentu.

Keluarga yang dilandasikasih sayang sangat penting bagi anak supaya anak dapat mengembangkantingkah laku sosial yang baik.Bila kasih sayang tersebut tidak 


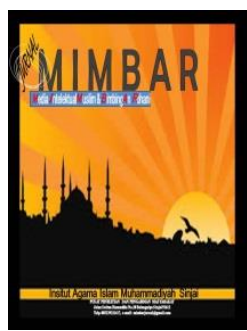

MIMBAR

Jurnall Media Intelektuall Muslim dan Bimbingan Rohani

Volume 5, No. 2, 2019

ISSN (print) : 2442-3217

ISSN (online) : 2716-3806

Homepage : http://journal.iaimsinjai.ac.id/indeks.php/mimbar

ada, maka sering kali anak akan mengalami kesulitan dalam hubungan sosial, dan

kesulitanini akan mengakibatkan berbagai macam kelainan tingkah laku sebagai upayakompensasi dari anak. Sebenarnya, setiap orang tua itu menyayangi anaknya,akan tetapi manifestasi dari rasa sayang itu berbeda-beda dalam penerapannya. Perbedaan itu akan nampak dalam pola asuh yang diterapkan.

Perkembangan anak penting dijadikan perhatian khusus bagi orangtua. Sebab, proses tumbuh kembang anak akan mempengaruhi kehidupan mereka pada masa mendatang.Jika perkembangan anak luput dari perhatian orangtua (tanpa arahan dan pendampingan orangtua), maka anak akan tumbuh seadanya sesuai dengan yang hadir dan menghampiri mereka. Dan kelak, orangtua juga yang akan mengalami penyesalan yang mendalam.Dampak negatif dari perkembangan anak yang kurang perhatian dari orang tuanya adalah anak menjadi nakal dan susah diatur. Dan dampak lain yang ditimbulkan adalah perusakan moral yang dialami anak yang kemungkinan diakibatkan dari salah bergaul dan berteman. Dan akhirnya, anak-anak inilah yang membawa dampak buruk bagi teman-temannya. ${ }^{4}$

Masih banyak orang tua yang salah dalam mengasuh anaknya, mereka lebih cenderung otoriter terhadap anaknya tanpa memberi kehangatan.Orang tua menggunakan kontrol, kekuasaan dan peraturan-peraturan yang di buat serta memaksa anaknya untuk menuruti semua yang di katakan.

\footnotetext{
${ }^{4}$ http://www.ayobukasaja.com/2012/06/konsep-dasar-psikologi-perkembangan..html diakses dari internet 10 April 2014.
} 


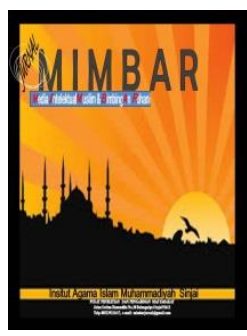

MIMBAR

Jurnall Media Intelektual Muslim dan Bimbingan Rohani

Volume 5, No. 2, 2019

ISSN (print) : 2442-3217

ISSN (online) : 2716-3806

Homepage : http://journal.iaimsinjai.ac.id/indeks.php/mimbar

Anak lahir dalam pemeliharaan orang tua dan di besarkan dalam

keluarga.Orang tua bertugas sebagai pengasuh, pembimbing, pemelihara dan sebagai

pendidik terhadap anak-anaknya.Setiap orang tua pasti menginginkan anak-anaknya menjadi manusia yang pandai, cerdas dan berakhlak. Akan tetapi jika anak diperlakukan secara otoriter anak tersebut akan cenderung merasa terkekang, merasa dibatasi kebebasannya, bahkan ada yang merasa tidak di sayangi orang tuanya. Sikap orang tua yang otoriter seperti ini yang dapat mempengaruhi sikap, cara berpikir bahkan kecerdasan mereka

Berdasarkan uraian di atas penulis mengangkat judul tentang "Pola Asuh Orang Tua yang Otoriter dalam Keluarga terhadap Perkembangan perilaku anak di Desa Kaloling Kecamatan Sinjai Timur”

\section{B. Rumusan dan Batasan Masalah}

\section{Rumusan Masalah}

Berdasarkan uraian latar belakang diatas,dapat dirumuskan permasalahan sebagai berikut:

a. Bagaimana pola asuh orang tua yang otoriter terhadap perilaku anak Desa Kaloling Kecamatan Sinjai Timur?

b. Bagaimana dampak yang ditimbulkan terhadap anak didik dengan otoriter Desa Kaloling Kecamatan Sinjai Timur?

\section{PEMBAHASAN}

\section{A. Tinjauan Tentang Pola Asuh}




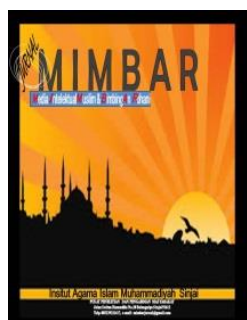

MIMBAR

Jurnall Media Intelektuall Muslim dan Bimbingan Rohani

Volume 5, No. 2, 2019

ISSN (print) : 2442-3217

ISSN (online) : 2716-3806

Homepage : http://journal.iaimsinjai.ac.id/indeks.php/mimbar

\section{Pengertian Pola Asuh}

Pola asuh adalah cara, bentuk atau strategi dalam pendidikan keluarga yang dilakukan oleh orangtua kepada anaknya. Strategi, cara dan bentuk pendidikan yang dilakukan orangtua kepada anak-anaknya sudah tentu dilandasi oleh beberapa tujuan dan harapan orangtua. Diharapkan pendidikan yang diberikan orangtua membuat anak mampu bertahan hidup sesuai alam dan lingkungannya dengan cara menumbuhkan potensi-potensi yang berupa kekuatan batin, fikiran dan kekuatan jasmani pada diri setiap anak. ${ }^{5}$ Pola asuh pada prinsipnya merupakan parental control. Pola asuh merupakan cara orangtua berinteraksi dengan anaknya, meliputi; pemberian aturan, hadiah, hukuman dan pemberian perhatian, serta tanggapan terhadap perilaku anak. peranan dan bantuan orangtua kepada anak akan dapat tercermin dalam pola asuh yang diberikan kepada anaknya. ${ }^{6}$

Setiap orang tua pasti menginginkan anaknya menjadi orang yang memiliki kepribadian yang baik, sikap mental yang sehat serta akhlak yang baik pula.Orang tua merupakan pembentuk kepribadian anak yang pertama kali, karena orang tua merupakan teladan bagi anak-anaknya. Menurut Zakiyah Daradjat kepribadian orang tua, sikap dan cara hidup merupakan unsur-unsur pendidikan yang secara tidak langsung akan masuk kedalam pribadi anak mereka yang sedang tumbuh. ${ }^{7}$

5 Admins Pola Asuh Orang Tua Diakses dari internet melalui www. Google. Com pada tanggal 10April 2014.

${ }^{6}$ Ibid.

${ }^{7}$ Darajat, zakiyah. Ilmu Jiwa Agama. ( Jakarta: Bulan Bintang.1996 ), h. 56. 


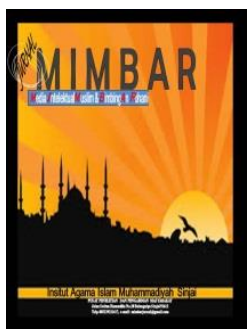

MIMBAR

Jurnall Media Intelektuall Muslim dan Bimbingan Rohani

Volume 5, No. 2, 2019

ISSN (print) : 2442-3217

ISSN (online) : 2716-3806

Homepage : http://journal.iaimsinjai.ac.id/indeks.php/mimbar

Pola asuh terdiri dari dua kata yaitu pola dan asuh. Menurut Kamus Besar

Bahasa Indonesia, pola berarti corak, model, sistem, cara kerja, bentuk (stuktur) yang tetap. ${ }^{8}$ Sedangkan kata asuh adalah menjaga ( merawat dan mendidik) anak kecil, membimbing, dan memimppin satu badan atau lembaga. Menurut Danny I. YatimIrwanto, pola asuh adalah pendidikan, sedangkan pendidikan adalah bimbingan secara sadar oleh pendidik terhadap jasmani dan rohani anak didik menuju terbentuknya kepribadian yang utama.

Jadi, pola asuh orang tua adalah suatu interaksi antara orang tua dan anak, dimana orang tua bermaksud untuk memberikan rangsangan kepada anaknya dengan tujuan untuk mengubah tingkah laku, pengetahuan serta nilai-nilai yang di anggap tepat oleh orang tua agar anak menjadi mandiri, tumbuh dan berkembang secara sehat dan optimal.

Berdasarkan beberapa pendapat di atas, maka pola asuh dapat didefinisikan sebagai upaya pemeliharaan seorang anak, yakni bagaimana orangtua memperlakukan, mendidik, membimbing dan mendisiplinkan serta melindungi anak, yang meliputi cara orangtua memberikan peraturan, hukuman, hadiah, kontrol dan komunikasi untuk mencapai kedewasaan sesuai dengan norma-norma yang diharapkan masyarakat pada umumnya.

\section{Bentuk-Bentuk Pola Asuh}

\footnotetext{
${ }^{8}$ Depdikbud. Kamus Besar Bahasa Indonesia. (Jakarta: Balai Pustaka. 1988), h. 54.
} 


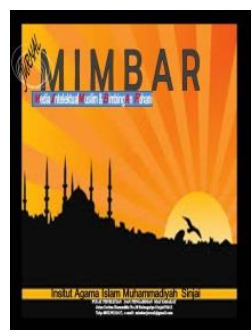

MIMBAR

Jurnall Media Intelektuall Muslim dan Bimbingan Rohani

Volume 5, No. 2, 2019

ISSN (print) : 2442-3217

ISSN (online) : 2716-3806

Homepage : http://journal.iaimsinjai.ac.id/indeks.php/mimbar

Beberapa ahli psikologi telah mengadakan pembagian gaya pengasuhan orang

tua dari sudut pandang yang berbeda, diantaranya yaitu:

a. Authoritarian (otoriter)

Pola asuh authoritarian adalah bentuk pola asuh dimana orang tua mengasuh anaknya dengan gaya pengasuhan keras. Orang tua menuntut kepatuhan yang tinggi pada anak, tidak boleh bertanya terhadap tuntutan orang tua, orang tua banyak menghukum bila remaja melanggar tuntutannya. Orang tua yang menerapkan pola asuh Authoritarian akan memberikan pengontrolan yang ketat terhadap perilaku anaknya. Namun kurang memberikan kesempatan atau berdiskusi.Artinya adanya penerapan disiplin yang ketat dan bersifat otoriter. Dengan pola asuh ini anak akan cenderung berkembang menjadi anak yang kaku, sulit menyesuaikan diri dalam situasi sosial, tidak percaya diri dan bahkan mengarah pada perilaku-perilaku agresif. ${ }^{9}$

b. Authoritative (demokratis)

Pola asuh yang paling konsisten dalam memberikan efek positif adalah pola asuh yang autoritatif dimana orang tua memberikan pengontrolan yang ketat dan juga disertai dengan kehangatan dalam berinteraksi. Bentuk pola pengasuhan authoritative ini orang tua lebih menjadikan dirinya panutan atau model bagi anak, orang tua hangat dan berupaya membimbing anak, orang tua melibatkan anak dalam membuat keputusan, orang tua berwenang untuk mengambil keputusan akhir dalam keluarga, orang tua menghargai didisiplin anak. Komunikasi yang terjadi dalam pola asuh ini

\footnotetext{
${ }^{9}$ Moh. Shohib, Pola Asuh Orang Tua, (Rineka Cipta, Jakarta, 1998), h. 12.
} 


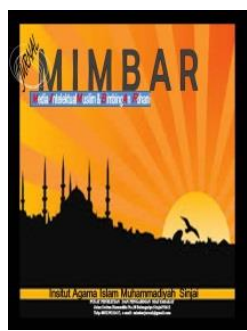

MIMBAR

Jurnall Media Intelektuall Muslim dan Bimbingan Rohani

Volume 5, No. 2, 2019

ISSN (print) : 2442-3217

ISSN (online) : 2716-3806

Homepage : http://journal.iaimsinjai.ac.id/indeks.php/mimbar

lebih bersifat timbal balik.Dan karena orang tua berupaya memberdayakan remaja

maka kontrol secara berangsur-angsur berpindah ke tangan anak.

c. Permisif

Pola asuh bentuk permisif adalah gaya pengasuhan dimana orang tua tidak mengendalikan, tidak menuntut, dan hangat kepada anaknya. Mereka tidak terorganisasi dengan baik atau tidak efektif dalam menjalankan rumah tangga, lemah dalam mendisiplinkan dan mengajar anak.Pola asuh permisif tidak menggunakan aturan-aturan yang ketat bahkan bimbingan jarang diberikan, sehingga tidak mengendalikan, mengontrol atau menuntut pada anak. Kebebasan di berikan secara penuh dan anak di izinkan membuat keputusan untuk dirinya sendiri, tanpa pertimbangan orang tua dan boleh berkelakukan menurut apa yang di inginkannya tanpa adanya kontrol dari orang tua. Anak harus belajar sendiri bagaimana harus berperilaku dalam lingkunga sosial, karena kurang diajarkan atau diarahkan pada peraturan-peraturan, baik yang berlaku di lingkungan keluarga atau masyarakat.Anak tidak di hukum walaupun sengaja melanggar peraturan, juga tidak ada hadiah bagi remaja yang berperilaku sosial dengan baik.Jadi remaja di biarkan berbuat sesuka hati dengan sedikit kekangan, memanjakan dan memenuhi kebutuhan remaja agar mereka senang. 


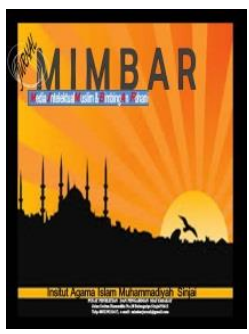

MIMBAR

Jurnall Media Intelektuall Muslim dan Bimbingan Rohani

Volume 5, No. 2, 2019

ISSN (print) : 2442-3217

ISSN (online) : 2716-3806

Homepage : http://journal.iaimsinjai.ac.id/indeks.php/mimbar

\section{d. Pola asuh penelantar}

Pola asuh penelantar akan menghasilkan karakteristik anak-anak yang moody, impulsive, agresif, kurang bertanggung jawab, tidak mau mengalah, Self Esteem (harga diri) yang rendah, sering bolos, dan bermasalah dengan teman. ${ }^{10}$

\section{B. Tinjauan Tentang Orang Tua Otoriter}

\section{Pola Asuh Orang Tua Otoriter}

Pola asuh orang tua otoriter yaitu pola asuh yang menekankan adanya kekuasaan orangtua, adanya hubungan yang kurang hangat antara orangtua dengan anak serta keberadaan anak yang kurang diakui oleh orangtua. Faktor pola asuh orangtua merupakan salah satu faktor yang mempengaruhi pembentukan kepribadian anak seperti anak akan menjadi tidak bahagia dan cendrung menarik diri dari pergaulan, suka menyendiri disamping itu sulit bagi mereka untuk mempercayai pihak lain dan prestasi belajar mereka di sekolah pun rendah.

Fokus pertama kali dalam pengasuhan otoriter adalah kontrol perilaku untuk memenuhi pengharapan orangtua.Pengasuhan ini sangat kaku, kepatuhan tidak adanya pertanyaan yang menuntut tanpa diskusi dan penjelasan.Keterangan dapat merupakan sebuah penawaran walaupun mereka tidak membuka peluang untuk menjelaskan keterangan tersebut.Orangtua yang authoritarian juga suka mengawasi, tetapi tidak mau mendengarkan anak-anak mereka. Mereka tidak begitu banyak berpartisipasi dalam aktifitas anak-anak mereka, mereka lebih bersifat lugas dan

\footnotetext{
${ }^{10}$ Ibid, h. 13
} 


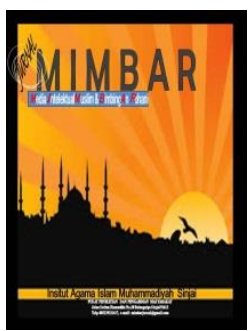

MIMBAR

Jurnall Media Intelektuall Muslim dan Bimbingan Rohani

Volume 5, No. 2, 2019

ISSN (print) : 2442-3217

ISSN (online) : 2716-3806

Homepage : http://journal.iaimsinjai.ac.id/indeks.php/mimbar

dingin. Perintah dan hukuman adalah rutin, berlangsung dari hari ke hari. Dari gaya

seperti ini ternyata bahwa anak-anak mereka pada umumnya tidak bahagia dan cendrung menarik diri dari pergaulan, suka menyendiri di samping itu sulit bagi mereka untuk mempercayai pihak lain dan prestasi belajar mereka di sekolah pun rendah. $^{11}$

Pola asuh orangtua yang otoriter yaitu pola asuh yang menekankan adanya kekuasaan orangtua, adanya hubungan yang kurang hangat antara orangtua dengan anak serta keberadaan anak yang kurang diakui oleh orangtua. Faktor pola asuh orangtua merupakan salah satu faktor yang mempengaruhi pembentukan kepribadian anak seperti anak akan menjadi tidak bahagia dan cendrung menarik diri dari pergaulan, suka menyendiri disamping itu sulit bagi mereka untuk mempercayai pihak lain dan prestasi belajar mereka di sekolah pun rendah.

Orang tua yang authoritarian juga suka mengawasi, tetapi tidak mau mendengarkan anak - anak mereka. Mereka tidak begitu banyak berpartisipasi dalam aktifitas anak - anak mereka, mereka lebih bersifat lugas dan dingin. Perintah dan hukuman adalah rutin, berlangsung dari hari ke hari. Dari gaya seperti ini ternyata bahwa anak - anak mereka pada umumnya tidak bahagia dan cendrung menarik diri dari pergaulan, suka menyendiri di samping itu sulit bagi mereka untuk mempercayai pihak lain dan prestasi belajar mereka di sekolah pun rendah. ${ }^{12}$

\footnotetext{
${ }^{11}$ Admins Pola Asuh Orang Tua. Op. cit.

${ }^{12}$ Ibid.
} 


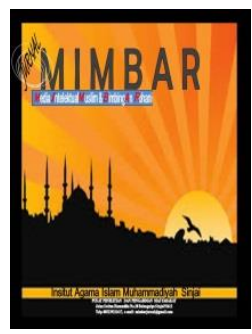

MIMBAR

Jurnall Media Intelektuall Muslim dan Bimbingan Rohani

Volume 5, No. 2, 2019

ISSN (print) : 2442-3217

ISSN (online) : 2716-3806

Homepage : http://journal.iaimsinjai.ac.id/indeks.php/mimbar

Pola asuh orang tua memiliki pengaruh yang besar terhadap perkembangan

moral anak ketika dewasa. Sayangnya banyak sekali orang tua yang tidak sadar dengan tindakan yang mereka lakukan kepad sikecil.Banyak orang tua yang menerapkan pola asuh yang salah karena berpatokan pada pengalaman masalaluh yang perna mereka rasakan. Pola asuh yang salah atau seringnya menghukum karena orang tua yang tidak bisa mengedalikan emosi.

\section{Aspek-Aspek Pola Asuh Otoriter}

Ada empat aspek-aspek pola asuh otoriter, yaitu:

\section{a. Aspek batasan perilaku (behavioral guidelines)}

Pada aspek ini, orangtua sangat kaku dan memaksa.Anak - anak sudah dibentuk sejak kecil sehingga mereka tidak mempunyai ruang untuk berdiskusi atau meminta keterangan. Cara yang digunakan untuk memaksakan petunjuk - petunjuk perilaku tersebut melalui cara - cara diktator, seringkali memakai hukuman yang berlebihan atau keras dan di luar kemampuan si anak untuk menjalankan hukuman tersebut. Keseluruhan tujuan dari gaya ini adalah untuk melakukan kontrol anak dan bukannya mengajari anak atau membantu anak untuk mengembangkan otonominya.

b. Aspek kualitas hubungan emosional orang tua-anak (emotional quality of parent child relationship)

Gaya pengasuhan ini mempersulit perkembangan kedekatan antara orangtua dan anak.Kedekatan yang sebenarnya didasari oleh saling menghormati dan satu keyakinan pada diri orangtua bahwa anak mempunyai kapasitas untuk belajar 


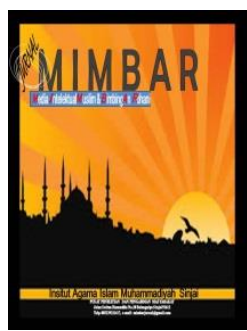

MIMBAR

Jurnall Media Intelektuall Muslim dan Bimbingan Rohani

Volume 5, No. 2, 2019

ISSN (print) : 2442-3217

ISSN (online) : 2716-3806

Homepage : http://journal.iaimsinjai.ac.id/indeks.php/mimbar

mengontrol dirinya dan membuat keputusan melalui petunjuk - petunjuk perilaku dan kapasitas kognitif yang mereka miliki.Gaya pengasuhan ini tidak mengakui proses individuasi pada anak dan pertumbuhan otonomi pada diri anak. Kedekatan yang dapat berkembang dengan gaya pengasuhan seperti ini adalah kedekatan semu karena kedekatan tersebut muncul dari rasa takut anak untuk tidak menyenangkan orangtua dari pada keinginan untuk tumbuh dan berkembang.

c. Aspek perilaku mendukung (behavioral encouraged)

Pada aspek ini perilaku orangtua di tunjukkan dengan mengontrol anaknya daripada mendukung anaknya agar mereka mampu berfikir memecahkan masalah.Orangtua sering melarang anaknya dan berperilaku negatif dan memberi hukuman.Jadi orangtua lebih memberi perintah daripada menjelaskan untuk melakukan sesuatu atau menyelesaikan masalah.

d. Aspek tingkat konflik orangtua - anak (levels of parent-child conflict)

Kontrol berlebihan tanpa kedekatan yang nyata dan rasa saling menghormati akan memunculkan pemberontakan pada anak. Dengan kata lain pengasuhan ini dapat menimbulkan banyak konflik antara orangtua dengan anak sekalipun hal itu tidak ditunjukkan secara terang - terangan. Konflik ini bisa muncul dalam bentuk perkelahian antara anak yang satu dengan yang lainnya. ${ }^{13}$

Berdasarkan uraian di atas dapat disimpulkan aspek-aspek pola asuh otoriter yaitu: aspek batasan perilaku (behavioral guidelines), aspek kualitas hubungan

\footnotetext{
${ }^{13}$ Ibid.
} 


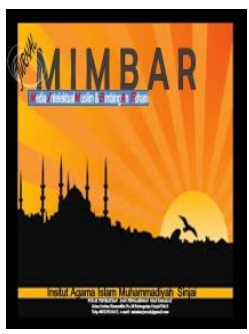

MIMBAR

Jurnall Media Intelektuall Muslim dan Bimbingan Rohani

Volume 5, No. 2, 2019

ISSN (print) : 2442-3217

ISSN (online) : 2716-3806

Homepage : http://journal.iaimsinjai.ac.id/indeks.php/mimbar

emosional orangtua - anak (emotional quality of parent-child relationship), aspek perilaku mendukung (behavioral encouraged), aspek tingkat konflik orangtua - anak (levels of parent-child conflict).

Orang tua dengan gaya "Otoriter" (Authoritarian Parentig) akan mendesak anak-anaknya untuk mengikuti petunjuk-petunjuk dan menghormati mereka. Untuk itu mereka tidak segang-segang menghukum anak secara fisik. Orang tua memberi batas-batasan pada anak sacara keras dan mengontrol mereka dengan ketat. Anakanak yang dibesarkan dalam keluarga seperti ini mengalami banyak psikologis yang dapat menghambat mereka untuk belajar. Di rumah, mereka cenderung cemas dan merasa tidak aman. Di sekolah, mereka juga tidak bisa bersosialisasi dengan baik dengan demikian mengalamimbanyak kesulitan dalam bergaul dengaan temantemannya. Mereka memiliki keterampilan berkomunikasi yang sangat rendah sehingga menimbulkan banyak hambatan psikologis. ${ }^{14}$

Pendidikan dalam keluarga memiliki nilai strategis dalam pembentukan kepribadian anak.Sejak kecil anak sudah mendapat pendidikan dari orang tuanya melalui keteladanan dan kebiasaan hidup sehari-hari dalam keluarga. Baik tidaknya keteladanan yang diberikan dan bagaimana kebiasaan hidup orang tua sehari-hari dalam keluarga akan mempengaruhi perkembangan jiwa anak. ${ }^{15}$

\footnotetext{
${ }^{14}$ Monty P. Satiadarma dan Fidelis E. Waruwu, Mendidik Kecerdasan, (Jakarta: Pustaka Populer Obor, 2003), 123-124.

${ }^{15}$ Syaiful Bahri Djamarah, Pola Komunikasi Orang Tua \& Anak dalam Keluarga: sebuah perspektif pendidikan islam, (Cet. I; Jakarta: Rineka Cipta, 2004), h. 24.
} 


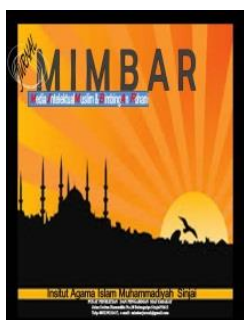

MIMBAR

Jurnall Media Intelektuall Muslim dan Bimbingan Rohani

Volume 5, No. 2, 2019

ISSN (print) : 2442-3217

ISSN (online) : 2716-3806

Homepage : http://journal.iaimsinjai.ac.id/indeks.php/mimbar

\section{Dampak Pola Asuh Otoriter}

Dalam kehidupan sehari-hari orang tua tidak hanya secara sadar, tetapi juga terkadang secara tidak sadar memberikan contoh yang kurang baik kepada anak. Misalnya, meminta tolong kepada anak dengan nada mengancam, tidak mau mendengarkan cerita anak, memberikan nasehat tidak pada tempatnya dan tidak pada waktu yang tepat, berbicara kasar kepada anak, membeda-bedakan anak, kurang memberikan kepercayaan kepada anak untuk melakukan sesuatu. Efek negative dari sikap da perilaku orang tua yang demikian terhadap anak misalnya, anak memiliki sifat keras hati, keras kepala, manja, pendusta, pemalu, pemalas. ${ }^{16}$

Anak yang dididik dengan otoriter mempunyai dampak negatif diantaranya:

a. Cenderung suka melawan dan kasar atau malah justru menjadi tidak mau berteman dan lebih menyendiri.

b. Anak akan meniru perilaku kekerasan orang tuanya terhadap orang lain.

c. Anak belajar mengekspresikan kemarahan dengan cara yang tidk sehat.

d. Anak belajar bahwa kita boleh melakukan kekerasan. ${ }^{17}$

\section{Perilaku anak yang dididik dan dibesarkan dengan otoriter}

Pola asuh otoriter menetapkan standar yang harus dituruti, biasanya dibarengi dengan ancaman-ancaman. Seperti anak harus mematuhi peraturan-peraturan orang tua dan tidak boleh membanta, orang tua selalu mencari-cari kesalahan anak dan kemudian menghukumnya, atau jika terdapat perbedaan pendapat antara orang tua

\footnotetext{
${ }^{16}$ Ibid., h. 26.

${ }^{17}$ Vitria Lazzarini, KDRT dan Pelecahan Seksual dalam Kehidupan Anak Usia Dini, (Jakarta: 2009),h. 13.
} 


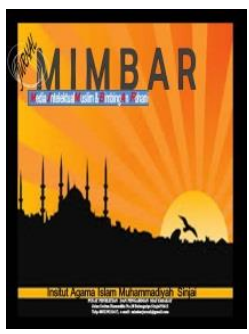

MIMBAR

Jurnall Media Intelektuall Muslim dan Bimbingan Rohani

Volume 5, No. 2, 2019

ISSN (print) : 2442-3217

ISSN (online) : 2716-3806

Homepage : http://journal.iaimsinjai.ac.id/indeks.php/mimbar

dan anak dinggap pembangkan.Perilaku anak yang dididik dan dibesarkan dengan otoriter meliputi:

a. Harga Diri

Kemungkinan besar yang terjadi pada anak adalah gagal mengakui individualitas mereka. Akhirnya anak-anak menderita rendah harga diri karena menganggap dirinya tidak berperan penting dan tidak culup valid menentukan keberadaan mereka ditengah masyarakat.

b. Kepercayaan diri

Anak-anak dengan orang tua otoriter selalu mengambil keputusan sepihak tenpa kompromidengan anak. Anak pun akan gagal mengakui keinginan karena naluri mereka selalu dikendalikan. Mereka juga tidak percaya akan kemampuan diri mengambil keputusan penting.

c. Kepatuhan

Karena cenderung dibatasi individualitasnya anak-anak akan selalu mengikuti perintah orang tua tanpa keraguan. Mereka tidak berani bereksperimen dalam menangani situasi. Bahkan tidak mampun berhadapan denga situasi stres dan tidak bisa mengesperesikan diri.

d. Menang sendiri

Orang tua selalu menetapkan aturan dan panduan agar anak mengikutinya tanpa mempertanyakan baik dan buruknya. Bila mereka gagal melakukan sesuatu 


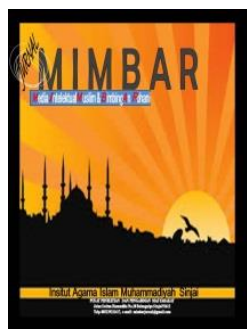

MIMBAR

Jurnall Media Intelektuall Muslim dan Bimbingan Rohani

Volume 5, No. 2, 2019

ISSN (print) : 2442-3217

ISSN (online) : 2716-3806

Homepage : http://journal.iaimsinjai.ac.id/indeks.php/mimbar

biasanya dikenakan hukuman. Anak-anak pun terbiasa untuk harus unggul dalam

kegiatan di luar sekolah atau di lingkingan masyarakat

e. Kesepian

Sementara orang tua sibuk memutuskan pedoman, anak-anak mulai merasa kesepian dan menarik diri. Kemudian pendiam dan menutup diri. Banyak kasus anak menjadi depresi karena mereka tidak mendapatkan perhatian yang layak untuk didengar dan dilihat sebagai individu.

\section{Tinjauan Tentang Perkembangan Perilaku Anak}

\section{Pengertian Perilaku}

Perilaku diartikan sebagai suatu aksi dan reaksi organism terhadap lingkungannya. Hal ini berate bahwa perilaku baru terjadi apabila ada sesuatu yang diperlukan untuk menimbulkan reaksi, yakni yang disebut rangsangan. Dengan demikian, maka suatu rangsangan tertentu akan menghasilkan reaksi atau perilaku tertentu. $^{18}$

Perilaku dari pandangan biologis adalah merupakan suatu kegiatan atau aktifitasorganisme yang bersangkutan.Jadi perilaku manusia pada hakikatnya adalah suatu aktifitas daipada manusia itu sendiri.

${ }^{18}$ Asmar Yetty Zein dan Eko Suriyani, Psikologi Ibu dan Anak, (Cet. 1; Yogyakarta: Fitramaya, 2005)., h. 23. 


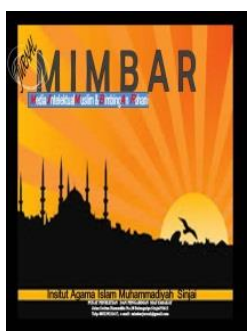

MIMBAR

Jurnall Media Intelektuall Muslim dan Bimbingan Rohani

Volume 5, No. 2, 2019

ISSN (print) : 2442-3217

ISSN (online) : 2716-3806

Homepage : http://journal.iaimsinjai.ac.id/indeks.php/mimbar

Pandangan behavioristik mengatakan bahwa perilaku sebagai respon terhadap

stimulus, akan sangat ditentukan oleh keadaan stimulusnya, dan individu atau organism seakan-akan tidak mempunyai kemampuan untuk menetukan perilakunya. ${ }^{19}$

\section{Jenis Perilaku}

Perilaku dibedakan menjadi dua yaitu perilaku yang alami dan perilaku operan.Perilaku alami yaitu perilaku yang dibawah sejak organism dilahirkan, yaitu yang berupa reflex-refleks dan insting-insting, sedangkan perilaku operan yaitu perilkau yang ditentukan melalui proses belajar. Perilaku yang refleksi merupakan perilaku yang terjadi sebagai reaksi secara spontan terhadap stimulus yang mengenai organism yang bersangkutan. ${ }^{20}$

Kebiasaan yang orang tua tampilkan dalam bersikap dan berperilaku tidak terlepas dari perhatian anak. Meniru kebiasaan hidup orang tua adalah suatu hal yang sering ank lakukan, karena memang pada masa perkembangannya, anak selalu ingin menuruti apa-apa yang orang tua lakukan. Jika anak dibesarkan dengan celaan, ia belajar memaki. Jika anak dibesarkan dengan permusuhan, ia belajar berkelahi. Jika anak dibesarkan dengan cemoohan, ia belajar rendah diri. Jika anak dibesarkan dengan toleransi, ia belajar menahan diri. Jika anak dibesarkan dengan dorongan, ia belajar percaya diri. Jika anak dibesarkan dengan pujian, ia belajar menghargai. Jika anak dibesarkan dengan sebaik-baiknya perlakuan, ia belajar keadilan. Jika anak dibesarkan dengan rasa aman, ia belajar menaruh kepercayaan. Jika anak dibesarkan

\footnotetext{
${ }^{19} \mathrm{Ibid}$.

${ }^{20}$ Ibid., h. 24.
} 


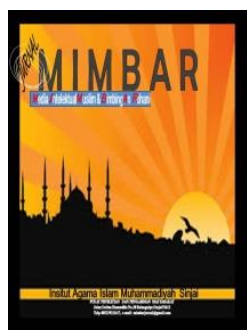

MIMBAR

Jurnall Media Intelektuall Muslim dan Bimbingan Rohani

Volume 5, No. 2, 2019

ISSN (print) : 2442-3217

ISSN (online) : 2716-3806

Homepage : http://journal.iaimsinjai.ac.id/indeks.php/mimbar

dengan dukungan, ia belajar menyenangi dirinya. Jika anak dibesarkan dengan kasih

saying dan persahabatan, ia menemukan cinta dalam kehidupan. ${ }^{21}$

\section{Tingkatan Masa Perkembangan Anak}

a. Masa Kanak-kanak Awal Early Chilhood Awal masa kanak-kanak berlangsung dari dua sampai enam tahun. Masa ini dikatakan usia pra kelompok karenapada masa ini anak-anak mempelajari dasar-dasar perilaku sosial sebagai persiapan bagi kehidupan sosial yang lebih tinggi yang diperlukan untuk penyesuaian diri pada waktu masuk kelas satu SD. ${ }^{22}$ Perkembangan biologis pada masa-masa ini berjalan pesat, tetapi secara sosiologis ia masih sangat terikat oleh lingkungan keluarganya. Oleh karena itu, fungsionalisasi lingkungan keluarga pada fase ini penting sekali untuk mempersiapkan anak terjun ke dalam lingkungan yang lebih luas terutama lingkungan sekolah ${ }^{23}$

b. Masa Kanak-kanak Akhir Later ChilhoodAkhir masa kanak-kanak atau masa anak sekolah ini berlangsung dari umur 6 tahun sampai umur 12 tahun.Selanjutnya Kohnstam menamakan masa kanak-kanak akhir atau masa anak sekolah ini dengan masa intelektual,dimana anak-anak telah siap untuk mendapatkan pendidikan di sekolah dan perkembangannya berpusat padaaspek intelek. Adapun Erikson menekankan masa ini sebagai masa timbulnya "sense of

\footnotetext{
${ }^{21}$ Vitria Lazzarini., Op.cit. h. 25.
}

22 Elfi Yuliani Rahmah, Psikologi Perkembangan, (Ponorogo : STAIN Ponorogo Press, 2005), h. 142.

${ }^{23}$ Muhibbin Syah, Psikologi Pendidikan Dengan Pendekatan Baru, (Bandung : PT Remaja Rosda Karya, 1995), 50. 
accomplishment" di manaanak-anak pada masa ini merasa siap untuk menerima tuntutan yang dapat timbul dari orang lain danmelaksanakan/menyelesaikan tuntutan itu. Kondisi inilah kiranya yang menjadikan anak-anak masa ini memasuki masa keserasian untuk bersekolah. ${ }^{24}$

c. Masa PuberPuberty Masa Puber merupakan periode yang tumpang tindih Karena mencakup tahun-tahun akhir masa kanak-kanak dan tahun-tahun awal masa remaja. Yaitu umur 11,0 atau 12,0 sampai umur 15,0 atau 16,0.Kriteria yang sering digunakan untuk menentukan permulaan masa puber adalah haid yang pertama kali pada anak perempuan dan mimpi basah pada anak laki-laki.Ada empat perubahan tubuh yang utama pada masa puber, ${ }^{25}$

d. Masa Dewasa Awal Early Adulthood Masa dewasa adalah periode yang paling penting dalam masa khidupan, masa ini dibagi dalam 3 periode yaitu:Masa dewasa awal dari umur 21,0 sampai umur 40,0. Masa dewasa pertengahan, dari umur 40,0 sampai umur60,0. dan masa akhir atau usia lanjut, dari umur 60,0 sampai mati.Masa dewasa awal adalah masa pencaharian kemantapan dan masa reproduktif yaitu suatu masa yang penuhdengan masalah dan ketegangan emosional, periode isolasi sosial, periode komitmen dan masa ketergantungan,perubahan nilai-nilai, kreativitas san penyesuaian diri pada pola hidup yang baru. Alat Berat. ${ }^{26}$

\footnotetext{
${ }^{24}$ Elfi Yuliani Rahmah, op. cit. h. 12.

${ }^{25}$ Ibid. h. 14

${ }^{26}$ Ibid. h. 15
} 


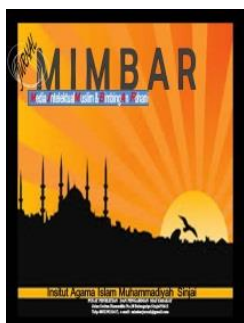

MIMBAR

Jurnall Media Intelektuall Muslim dan Bimbingan Rohani

Volume 5, No. 2, 2019

ISSN (print) : 2442-3217

ISSN (online) : 2716-3806

Homepage : http://journal.iaimsinjai.ac.id/indeks.php/mimbar

e. Masa Dewasa madya (Middle Adulthood). Masa dewasa madya ini berlangsung dari umur empat puluh sampai umur enam puluh tahun. Ciri-

f. ciri yangmenyangkut pribadi dan sosial pada masa ini antara lain, masa dewasa madya merupakan periode yang ditakuti dilihat dari seluruh kehidupan manusia. wisata, masa dewasa madya merupakan masa transisi, dimana pria dan wanita meninggalkan ciri-ciri jasmani danprilaku masa dewasanya dan memasuki suatu periode dalam kehidupan dengan ciri-ciri jasmani dan prilakuyang baru. ${ }^{27}$

g. Masa dewasa madya adalah masa berprestasi. Menurut Erikson, selama usia madya ini orang akanmenjadi lebih sukses atau sebaliknya mereka berhenti stagnasi, Pada masa dewasa madya ini perhatian terhadap agama lebih besar dibandingkan dengan masasebelumnya, dan kadang-kadang minat dan perhatiannya terhadap agama ini dilandasi kebutuhan pribadidan sosial.

h. Masa Usia LanjutLater Adulthood Usia lanjut adalah periode penutup dalam rentang hidup seseorang. Masa ini dimulai dri umur enam puluh tahun sampai mati, yang di tandai dengan adanya perubahan yang bersifat fisik dan psikologis yang semakin menurun. ${ }^{28}$

\footnotetext{
${ }^{27}$ Ibid. h. 17

${ }^{28}$ Ibid. h. 18
} 


\section{DAFTAR PUSTAKA}

Admins Pola Asuh Orang Tua Diakses dari internet melalui www.Goole. Com pada tanggal 10 April 2014.

Anak Bugis, Pengertian Psikologi Perkembangan Anak kapanpunbisa.blogspot.com. Diakses dari internet pada tanggal 10 April 2014.

Darajat, zakiyah.Ilmu Jiwa Agama. Jakarta: Bulan Bintang.1996.

Departemen Pandidikan dan Kebudayaan, Kamus Besar Baasa Indonesia, Balai Pustaka, Jakarta, 1995.

Depdikbud.Kamus Besar Bahasa Indonesia. Jakarta: Balai Pustaka. 1988.

Desmita, PsikologiPerkembangan Peserta Didik, Cet. IV; Bandung: PT. Remaja Rosdakarya, 2012.

Lazzarini Vitria, KDRT dan Pelecehan Seksual dalam Kehidupan AUD, 2011.

Mahmud Muhammad Al-Jauhari Muhammad Abdul Hakim Khayyal. 2005. Membangun Keluarga Qur'ani. Amzah.

Moleong Lexy J., Metode Penelitian Kualitatif, Edisi Revisi, Bandung: PT Remaja Rosdakarya, 2004.

Moleong,Teknik-Analisa-Data-Kuantitatif-Dan-

Kualitatif.http://tizarramawan.wordpress.com.2009. Diakses dari internet melalui www.Google.Com pada tanggal 10 April 2014.

Muh. Sohib, Pola Asuh Orang Tua, PT. Rineka Cipta, Jakarta, 1998.

Nana Syaodi, Metode penelitian pendidikan, Cet. I; Bandung: PT Remaja Rosda Karya, 2005.

Poedarminta, W.J.S. 1986. Kamus Besar Bahasa Indonesia. Jakarta: Balai Pustaka.

P. Satiadarma, Monty. Dan Fidelis E. Waruwu. Mendidik Kecerdasan. Jakarta: Pustaka Populer Obor. 2003

Syaiful Bahri Djamarah, Pola Komunikasi Orang Tua \& Anak dalam Keluarga, Cet. I; Jakarta: Rineka Cipta, 2004. 